\title{
Challenges and Prospects of Sports Administration in Tertiary Education in Nigeria
}

\author{
Deemua G. A. (Ph.D)*, Stanley C. Alaubi \\ Department of Human kinetics and Health Education Faculty of Education, University of Port Harcourt Rivers \\ State, Nigeria
}

*Corresponding Author: Deemua G. A. (Ph.D), Department of Human kinetics and Health Education Faculty of Education, University of Port Harcourt Rivers State, Nigeria

\begin{abstract}
The general dissatisfaction with sports administration in educational process especially higher education in Nigeria has given rise to several efforts to find more effective approaches to the participation of the young. The influenced expansion in our university system may be an answer to the insatiable demand for university education, but we seem to have taken an action which may infact compound the problem that we are supposed to solve. This paper therefore recommends among others that Nigeria tertiary institutions would have to acquire the major tools of internalization - ICT, which may become a management learning, and research tool. With appropriate develop ICT capacity, Nigeria tertiary institutions would be reducing the time and space that have separated her for too long from the world epicenters of internalization, hence, improving the totality of sports administration.
\end{abstract}

Keywords: Challenges and Prospects of Sports Administration

\section{INTRODUCTION}

Tertiary education is the post secondary education. NPE (2004) emphasized that tertiary education covers the post-secondary section of the national education system which is given in universities, polytechnics and colleges of Technology including such courses as are given by the Colleges of Education, the Advanced Teacher Training Colleges, correspondence colleges and such institutions as may be allied to them. The aims of this level of education according to NPE (2004) are:

a. the acquisition, development and inculcate of proper value-orientation of the survival of the individual and society.

b. the development of the intellectual capacities of individuals to understand and appreciate their environment;

c. the acquisition of both physical and intellectual skills which will enable individuals to develop into useful member of the community;

d. the acquisition of an objective view of the local environment.

The management of tertiary education is the burden of the federal and state governments, not until recently when permission was granted to private individuals to own, organize and manage university education in the country. (Alimba, 2007). The purpose of this paper is to trace the challenges of sports administration in tertiary education in Nigeria.

Tertiary education is in its modern form came to Nigeria from Britain, mainly as a fallback of colonial education system. Thus, Great Britain installed a replica of its tertiary education in the country with the establishment of the University College, Ibadan in 1948 as a college of the University of London (Anyebe, 2008). For purpose of this paper, unless otherwise specified in the tertiary education.

It can be recalled that Nigeria adopted a federal constitution in 1954 and tertiary education was placed on the concurrent legislative list. In order to avoid an unbalanced development and wasteful duplication that may arise from the federal and regional governments' quest for establishment of universities and tertiary institutions, the federal government set up the Ashby Commission in 1959. The commission which was mandated to review manpower needs for the whole country and make 
recommendations for a structure of education for the 1970's submitted its report in October, 1960. The detail recommendations contained in the report touched on every facet of education in sports in Nigeria-primary, secondary and sixth form education, teacher training, technical education, agricultural and veterinary education and university education.

Eze (2015) stated that the necessity for administration of sports programme in tertiary schools across the country cannot be over emphasized, if consideration should be given to the benefit that sport possesses. Sport is a general physical activity of competitive nature. Sports involve contest against an opponent, adversary, space, time obstacle, or natural force, thus, the aim is usually victory.

Paper administration of sports activities in school at all level enhances the level of students and even teacher's participation in school sports and the over success of intramural sports programme in a school. Administration of intramural sports tends to give sports programme its deserved directions and place in school (Eze, 2015). Adesina (2004), Ajah (2002) and Aku (2000) stated that an effective administration of sports simply means ensuring that the necessary materials needed for intramural sports programme are readily available.

Ladani (2008) stated that administrative practices are parameters or indices used to enhance the development of sports in educational institutions in Nigeria. Such indices for sport administration or management practices which may also serve as administrative strategies for intramural sports administration may include finance, personnel, athletes recruitment, sports facilities, sports equipment, organizational structure, sports policies, athletes motivational practice, students participation in sports, and public relation services in sports.

\section{DEMAND FOR SPORTS ADMINISTRATION IN TERTIARY EDUCATION}

The value of sports on behavior is quite overwhelming. Constant (2000) as cited in Harvey (2002) identified three dimensions in which sports can make contributions. These are social cohesion, citizenship and moral qualities dimension. However this can be made possible when it is perceived as common value in which everybody has a stake in the challenges and belong to the same culture. Sporting activities in Nigeria are organized and administered in the school system under the auspices of the school administrators and supervised by experts in the field (Ojeme, 2002): In Nigeria, sporting activities are undertaken in schools especially in tertiary education with the aim to build in the individual, a sound mind in a healthy body. Also this is to meet the physical, emotional, social and intellectual needs for students. Amuchie (2003) stressed that institutional sports are aimed at identifying sports skills as well as meeting health needs, and the promotion of optimum development of students.

Sports are an extra-curricular activity aimed at developing students' physical, emotional, mental and social wellbeing. It builds up psychosocial and motor skills of the individuals. Sports by their nature are social activities that build up team spirit, cooperation, competiveness, good behavior and morale including compliance to moral and societal norms. Sports as a social institution factor has over time assumed an influential status. Mars (2003) noted that sports tend to exert more influence on people's behavior than religion or politics. The level of effects may vary from one country to another or from one locality or state to another, although national and international sports seem to exert equal force (Mars, 2003).

In order to achieve the above aim of sports, sports activities are therefore been organized for students to participate on either within a school system. Sports are those experiences and activities that are organized for all students within the walls of an educational institution or school. Sports provide students the opportunity of developing necessary motor skills through formal learning, according to Slade (1999) cited by Emoghene (2015) is a necessary ingredient for the development of excellent sports performance in later year. In the same vein, failure to appropriately guide the child may prepare the way for future failure (Aluko \& Adodo, 2011).

One way in which students can be properly exposed to early and formal organized physical education/activities and sports to develop their motor skills which in turn enhances sports skill for future sports performance is through proper and regular organization and administration of intramural sports in tertiary schools. Sport is a recreational programme organized within school, college, and university setting involving teams that compete regularly. Intramural sports, according to Money, Onohwakpor and Odedede (2016) is the second level of participation in physical education in schools 
and it consists of activities and competition amongst students within the confined of one institution or school. Intramural level of participation in physical education, according to them, is geared towards the abilities and skills of the entire students' body and consists of voluntary participation in games, sports and other activities. Common examples of intramural sports include inter-house, inter-class or inter-hostel sports competitions.

Eke (2003) stated that intra-mural sports programme in school is rational and goal directed. It aimed at promoting wellness among school students as well as allowing those who do not compete at an elite level the opportunity to be active. Eke (2003) also stated sports administration could be viewed as a way of ensuring that sports activities are properly designed for all students to take part. According to (Mark, 2001) Sports programme are planned activities involving sporting activities for people's participation. Adedeji (1996) stated that sports programme is set plans to provide opportunities for people to engage themselves inn active sports. This according to Eze (2015) means that sports programme is geared towards involving people to regular participation in sports activities of their choice. It is clear indication that sports programme demands planning as well as providing material and human resources for it to be functional in schools in Nigeria. Adesanya (2004) stated that sports programme provide opportunities for play during free time and hence lead to the mastering of skills learn during instructional classes. This can only be achieved through proper administration.

Udoh (2001) expressed the view that the success of sports administration in Nigeria now and in the future depends to a large extent on the involvement of well qualified physical educators (sports administrators). The success or otherwise of any sports programme depends to a great extent on the personnel available to handle it. For instance, in a situations where there is money to run the programme, there are facilities and equipment and there are interested students, yet nothing gets done until the other element that is qualified personnel is present. This is why Omoruan (1996) maintained that all programmes, sports inclusive succeed or fail in direct proportion to the appropriate decisions and actions of those who are responsible for administering them.

\section{Challenges}

Some of the problems which sports administration is faced within tertiary education with regards to administration of sports programme according to Eze (2015) are related to funds, facilities, equipment, personnel, supervision, public relation; scheduling activities e.t.c. Agwuike (2007) observed that there is a dearth of physical education specialists. Even those that specialize in physical education prefer to handle other subjects leaving out physical education prefer to handle other subjects leaving out physical education to suffer. In such a situation, there is ineffective and inefficient implementation of the strategies for achieving policy aspiration and objectives.

The place and importance of indentifying strategies adopted by sports administrators towards ensuring successful management of intramural sports programme in secondary schools cannot be overemphasized. Strategy according to Horby (2001) is a plan that is intended to achieve a particular purpose. Prahelca (1993) stated that strategy is a plan or technique of action to achieve result as in secondary schools sports programme. Omoruan (1996) opined that the achievement of successful intramural sports programme management in tertiary schools require proper planning, adequate sports facilities and equipment, adequate personnel for proper supervision of the programme, motivation of staff and students as important strategies. Without putting in place a better strategy, achieving a successful sports programme and its objective(s) would always result to failure Prehalald, 1993 \& omoruan, 1996). Better strategies remain the basic factor towards achieving the intended objectives and successful intramural sports programme in secondary schools.

\section{REBRANDING OF TERTIARY EDUCATION SPORTS}

Omoruan (1996) listed some factors that have considerable influence on management strategies. They include location, school type, age and gender. However, Obi (2001), opined that location and gender have greater influence on sports programme. In school, there are people trained to teach sports (Physical Education) and as well handled sports administration. Those who are professionally trained to teach physical education and administer sports in the school are sports administrators. Sports administrators place key role in the organization and management of sports programme in schools at all level. As a matter of fact, the success and level of students and other staff involvement and active participation in sports in a school is strongly depended on the school sports administrators. However, the extent at which the school sports administrators achieve his/her goals especially on the area of 
intramural sports management is depended on the strategies they adopted in their management functions and processes.

\section{CONCLUSION}

The country has to make a concerted effort to overcome the social and institutional factors that impede its development aspirations of sports administration. In this age of globalization, education is a key tool for strengthening a nations capacity to become a full member of the emerging global society. Nigeria therefore, has to work hard to change its global fortunes for the better by systematically planning its education system (primary to tertiary) with emphasis on quality and excellence with regards to sports. Above all, our tertiary education should be development-oriented with emphasis on training creative minds needed for the continuous regeneration of society as opposed to certificate-oriented education to achieve optimal performance in tertiary education sports activities.

\section{RECOMMENDATIONS}

1. curriculum reforms that promote the inculcation of the generic skills (commission, inter-personal skills, adaptability, IT-fluency, creativity and lifelong learning skills so valued in today's knowledge economy), while de-emphasizing narrow and premature specialization. This means that we should refuse to be narrow specialist but have the ability to see life as long a connected whole and not as a set of disconnected realities. We should also be life-long learners, people with a perpetual thirst for knowledge, a spirit of inquiry, a perpetual search for self-improvement, making the best of every opportunity to renew and enrich our understanding of life and its demands.

2. Tailors teaching, research and service functions to the needs of the immediate society - being practically involved in thematic and problem-oriented societal/human activities and generating/disseminating knowledge from these to enrich the world pool of knowledge.

3. Inclusion of sports programme at all level of education with adequate financing and personnel to enhance sports administration in the country.

\section{REFERENCES}

[1] Adesina, S., 2004. Some aspect of school management of physical and sports. Ibadan: Education industries (Nig) Ltd.

[2] Alimba, N.C. (2007). Community participation in the management of the education system: The Nigerian experience in African Journal of Historical Science in Education 3(1) May, 97-1 10.

[3] Aliu, Y.O. (2005). The essence of University, being a lead paper presented at a capacity building workshop for non-academic/non-teaching staff of tertiary institutions, held at Kongo Conference Hotel, Zaria on the $27^{\text {th }}$ and $28^{\text {th }}$ July.

[4] Aluko, K. and Adodo, S.M. (2011). A Conceptual analysis of school sports development in Nigeria. International Multi-Disciplinary Journal, Ethiopia. 5(5), 394-403.

[5] Amuchie, F. A. (2003). Sports in University life with Reference to Nigeria Universities (1984-2003). Universiade conference, DAEGU Facing the Challenges. Yeungnam: Korea.

[6] Anyebe, A.A. (2006). Planning of higher education in Nigeria being a paper presented at a workshop organized by research and curriculum development unit (RCDU) in collaboration with Carnegie Corporation Project, USA Field at IDR, Ahmadu Bello University Zaria.

[7] Anyebe, A.A. (2008). Repositioning tertiary institutions in the actualization of millennium development goals (MDGs) by 2015, being a lead paper presented at the Niger State Polytechnic 2 National Conference (NIPOLY 2008) held at the Resource Centre, Bida Campus, $5^{\text {th }}-8^{\text {th }}$ August, 2008.

[8] Ayo, J.E. (1988). Development planning in Nigeria (Ibadan: University Press Ltd.)

[9] Baikie, A. (2002). Recurrent issues in Nigeria education G.S. Tseja (ed) Zaria: Tamaza publishing company Ltd.

[10] Eke, F.J., ( 2003). Mass media-a strong Installment for sports marketing Journal of NAPHER-SD, 2(I): 90-94

[11] Emoghene, O.B. (2016). Attitude of Teachers towards Students Participation in School Sports in Delta Central Senatorial District. A Dissertation Submitted to the Department of Human Kinetics and Health Education, Delta State University, Abraka.

[12] Eze, U W. (2015). Determinants of Effective Administration of Intramural Sports Proararnme of Secondary School in Nsukka Local Government Area of Enugu State, Nigeria. World Journal of Management and Behavioral Studies 3(2): 52-56. 
[13] Daily Trust, August 26, 2009.

[14] Federal Government of Nigeria: Ashby Commission Report, 1960.

[15] Federal Government of Nigeria: Merger of Universities of Technology in 1984 Bulleting of NUC.

[16] Federal Government of Nigeria: 25 Years of Centralized University Education in Nigeria

[17] in 1988 NUC Bulleting

[18] Federal Government of Nigeria: The 1962-68, 1970-74, 1975-80 and the 1981 - 85 Plan Documents.

[19] Federal Government of Nigeria: Bulletin of the National Board for Technical Education 2000.

[20] Harvey, J. (2002). Sports and citizenship policy. A shift toward a new normative frame work for evaluating sport policy in Canada. www.google.com.

[21] Hornby A. S (2001) Oxford Advanced Learners Dictionary of Current English. Oxford University Press.

[22] Ladani (2008) An Introduction to Sports Management, Printed and Bound by Sunjo A.J. Global Links Ltd, Kaduna, Nigeria.

[23] Mark, J.O., (2001). Physical Education and its Implication for the Development of Sports in Nigeria; the JONAPHER, 2(2): 105-108

[24] Mars, H.V., (2003). Authentic University Experience for every Student through Sports Education. A Possibility Universiade Conference.

[25] Ojeme, E.O., (2000). School Sports Development in Delta State in the New Millenium; Problems and Prospects. Keynote Address at the N.S.S.F Delta State Assembly, Asaba.

[26] Omoruan, J.O, (1996). A Handbook on Physical Education and Recreation. Zaria Asemowu publisher.

Citation: Deemua G. A. (Ph.D), Stanley C. Alaubi. "Challenges and Prospects of Sports Administration in Tertiary Education in Nigeria" International Journal of Sports and Physical Education (IJSPE), vol 6, no. 3, 2020, pp. 08-12. doi: https://doi.org/10.20431/2454-6380.0603002.

Copyright: (C) 2020 Authors. This is an open-access article distributed under the terms of the Creative Commons Attribution License, which permits unrestricted use, distribution, and reproduction in any medium, provided the original author and source are credited. 